\title{
Tourism and economic growth in Portugal: an empirical investigation of causal links
}

\author{
Turismo e crescimento económico em Portugal: análise das relações de causalidade
}

\section{João Paulo Cerdeira Bento}

University of Aveiro, Department of Economics, Management, Industrial Engineering and Tourism; Research Unit in Governance, Competitiveness and Public Policy, Campus de Santiago, 3810-193, Aveiro, Portugal, jpbento@ua.pt

\begin{abstract}
This study uses quarterly time series for the period from 1995 to 2015 to assess the temporal causal link between tourism and economic growth based on the hypothesis according to which tourism development precedes economic growth. It adopts a disaggregated approach to study the effects of both domestic tourists and foreign tourists on economic growth. Seasonally adjusted tourist arrivals are used to represent tourism activity. This study employs time series cointegration methods that are capable of accommodating structural breaks. The results show that the Portuguese case supports the tourism-led growth hypothesis. There is evidence of a long run cointegration relationship between the real gross domestic product and arrivals at tourist's accommodation establishments of both domestic tourists and foreign tourists. Long run unidirectional Granger causality exists running from domestic tourists to real gross domestic product, but not vice versa. The findings indicate that domestic tourism promotes economic growth. The main policy implication is that policy makers should contribute to tourism development and encourage tourism opportunities in domestic markets by targeting not only foreign tourists, but also domestic tourists to ensure the longterm success and strategic planning of the tourism sector in Portugal.
\end{abstract}

Keywords: Tourism-led growth hypothesis, tourists, cointegration and causality analysis, structural breaks, Portugal.

\section{Resumo}

Este estudo utiliza séries temporais e dados trimestrais para o período de 1995 a 2015 para avaliar a relação de causalidade de Granger entre o turismo e o crescimento económico. O estudo testa a Tourism Led Growth Hypothesis. A variável do turismo no modelo econométrico é desagregada em chegadas dos turistas nacionais e chegadas dos turistas estrangeiros. O estudo faz uma análise da cointegração e causalidade e os testes de raíz unitária têm em conta a possibilidade de existência de quebras estruturais nas séries temporais. A hipótese em questão é válida no caso Português. Existe uma relação de cointegração a longo prazo entre o produto interno bruto e as chegadas dos turistas nacionais e dos turistas estrangeiros em estabelecimentos de alojamento. Existe também uma relação de causalidade a longo prazo entre os turistas nacionais e o produto interno bruto. A mensagem principal deste estudo é salientar o papel dos turistas nacionais na promoção do sector do turismo e do crescimento económico em Portugal.

Palavras-chave: Tourism Led Growth Hypothesis, turistas, análise da cointegração e causalidade, quebras estruturais, Portugal.

\section{Introduction}

The 2015 Report on Competitiveness of Travel and Tourism states that the direct contribution of the travel and tourism sector to GDP was around 10 billion euro ( $6 \%$ of total GDP) in 2014 and is forecast to rise by $2.5 \%$ per annum from 2015 2025 to approximately 14 billion euro or 7\% of GDP in 2025 (WTTC, 2015). This sector is of great importance for the Portuguese economy reflecting the economic activity generated by industries such as hotels, travel agents, airlines and other passenger transportation services, and the activities of the restaurant and leisure industries directly supported. The increasing growth of tourism and hospitality industry is now widely recognized for its economic contribution supporting approximately 8 million foreign visitors each year. Nonetheless, residents as tourists are playing an increasing important role and have been increasing steadily over the course of the past decade. Therefore, it is important to uniformly realize the importance of the contribution of travel and tourism by residents and non-residents to tourism development plans or programs in the long term. This empirical investigation is particularly interested in assessing the contribution of the domestic tourism market to economic growth. The rationale for this study is therefore to highlight that the domestic tourism market is a sector with growth potential. The purpose of this research study is to assess the impact of the domestic tourism market development, alongside international tourism, on Portugal's economic growth in the long run.

According to the National Institute of Statistics the motives for travelling by residents are visits to families or friends, but tourism trips are also significantly connected with leisure, recreation and holidays. Domestic tourism provides opportunities to those operating in the tourism industry by generating visitor spending in domestic holidays and providing support to tourism operators in off-season months. Countries with a strong domestic tourism sector are usually better prepared to endure fluctuations in international demand due to economic depression, terrorist attack or even natural disaster. The context of this research relates to domestic tourism development and the objective of the National Strategic Plan for tourism that is to "accelerate the growth of domestic tourism" (Daniel \& Rodrigues, 2010).

This study contributes to the debate on whether tourism, and particularly domestic tourism development, notwithstanding the development of international tourism demand, contributes to the growth of economies. Therefore, it examines the hypothesis of "tourism-driven" economic growth in Portugal by using the formulation and specification of econometric models related to the tourism-led growth hypothesis. The abundant tourism literature on this topic located no empirical 
study based on one country such as Portugal using time series observations. However, the empirical literature in the area has used extensively panel data analysis. Therefore, the validation of the hypothesis and the use of the time series techniques can be extended readily to the time series setting for Portugal. This empirical investigation will assess the cointegration and causality relationships between tourism activity and economic growth. These are econometric techniques that are widely recognized in the existing literature.

In evaluating this literature, the studies used mainly an aggregate measure of tourism activity. The preferred variables are usually the total number of tourist arrivals or total tourism earnings. The tourism-led growth hypothesis is usually validated using this type of variables. This choice is not without any limitations given that this data does not take into account the tourism source markets, trends, composition and spending patterns of tourist arrivals and tourism market segmentation. In order to overcome the aggregation biais, this study decomposes tourist's arrivals into domestic tourist arrivals and international tourist arrivals.

The findings of this research will provide new perspectives on the relative significance and contribution of domestic tourism to economic growth. In this sense, the contribution of this specific study is on answering the question of whether and how domestic tourism can contribute to economic growth. The outcome of this empirical study will provide insights to governments whether they should continue to promote tourism related activities focusing on upgrading and modernization, quality, innovative, and attractive tourism services to domestic consumers, while maintaining a stable political and economic environment for tourism planning and development to gain market shares on the domestic and global market places. This study expands upon the existing research base on the economic growth hypothesis in two ways. First, the tourism indicator is decomposed into two components to contemplate the aggregation bias. Second, it invokes the use of econometric techniques in cointegration and causality analysis in which structural breaks can be automatically detected from data. Empirical studies on the relationship between tourism and growth often fail to take into account the extent to which structural breaks can affect estimation results. Omitting that structural breaks exist in the majority of the series can lead to erroneous conclusions. The time series analysis accommodates potential structural breaks that could undermine the research findings and lead to spurious regression results.

The remainder of the paper is organized in the following manner. Section 2 begins with a brief review of the literature around the theme of a tourism-led growth hypothesis, while section 3 describes the data and the econometric methods. The empirical findings are presented and discussed in section 4. Conclusions are in section 5 .

\section{Brief review of earlier studies}

The pioneering studies that have analysed the contribution of tourism to economic development can be found in the economic growth literature because tourism generates foreign exchange earnings and fiscal revenues for governments, and favours employment (Archer, 1995; Ghali, 1976; Lanza \& Pigliaru, 2000; Marin, 1992; West, 1993). Since then, the first paper that formally confirmed the tourism-led growth hypothesis through cointegration and causality tests for the case of the Spanish economy was published in 2002 (Balaguer \& Cantavella-Jordá, 2002). Several other time series studies showing the relationship between tourism and economic growth reported a long run equilibrium relationship and evidence for causality among the variables of interest specifically for southern European Mediterranean countries (Cortés-Jiménez \& Pulina, 2010; Dritsakis, 2004; Eeckels, Filis, \& Leon, 2012; Gunduz \& Hatemi-J, 2005; Katircioglu, 2007; Katircioglu, 2009; Katircioglu, 2009; Kim, Chen, \& Jang, 2006; Massidda \& Mattana, 2013; Nowak, Sahli, \& Cortés-Jiménez, 2007).

Based on the economic theoretical framework behind the tourism-led growth hypothesis, studies have appeared trying to understand the temporal relationship between tourism and economic growth for different developed and developing countries at the national and regional levels using different estimation methods (Brida, Carrera, \& Risso, 2008; Brida \& Giuliani, 2013; Corrie, Stoeckl, \& Chaiechi, 2013; Munjal, 2013). In terms of econometric methods, the review of the literature shows an increasing diversification in the use of econometric techniques that can be classified into three major sets according to the methodology applied: time series, panel data and cross-sectional data (Pablo-Romero \& Molina, 2013). The techniques used in these studies range from univariate and multivariate econometric techniques (e.g. Johansen cointegration approach, ARDL approach to cointegration, recursive Granger causality, Toda-Yamamoto approach to Granger non-causality), to inpute output models, social accounting matrix and applied computable general equilibrium models which make use of the tourism satellite accounts in the national accounting systems and input-output tables (Akkemik, 2012; Carrascal Incera \& Fernández, 2015; Munjal, 2013). There are studies that attempt to further verify the validity of the tourism-led growth hypothesis in a multivariate model derived from the Solow growth theory and from the CobbDouglas production function to justify the role of tourism in economic growth (Tang \& Tan, 2013). A formal macroeconomic general equilibrium model, that intertemporally optimizes agents with constant exogenous saving rate and fixed level of technology representing tourism production, is employed to analyse the impacts on economic growth of a small tourism-driven economy caused by an increase in the growth rate of international tourism demand (Schubert, Brida, \& Risso, 2011). Some scholars have tested the dependence between GDP and tourism's growth rates using a copula-based GARCH approach to explore the long run equilibrium relationship, short-run causality and to address volatility (Pérez-Rodríguez, Ledesma-Rodríguez, \& SantanaGallego, 2015).

The time series techniques are the pioneering method in this type of research. Many studies have been carried out with this method providing overall prove for the existence of a univocal connection between tourism and economic growth. One 
limitation of the literature covering studies based on time series, and referring to country specific assessments, was the lack of studies investigating the tourism-led growth hypothesis specifically in Portugal. In this sense, Table 1 reports indicative studies showing the relationship between tourism and economic growth in Portugal. The relationship between tourism and economic growth is an active area of research and the empirical evidence for Portugal is mainly based on empirical studies using panel data. These studies use a larger number of explanatory variables, larger sample and have longer time periods under analysis allowing for a greater depth in the relationships between variables. Despite the econometric complexity derived from the use of many variables and heterogenous data, studies based on panel data and cross-sectional data affirmed that there is a relationship between tourism and economic growth. In all studies, specialisation in tourism is a determing factor of economic growth and it is of importance to a country to specialise in tourism in order for tourism to affect economic growth.

Table 1 - Overview of published studies on the linkage between tourism and economic growth in Portugal.

\begin{tabular}{|c|c|c|c|c|}
\hline Indicative study & Econometric method & Period & Tourism variable & Causality \\
\hline Lanza et al. (2003) & Panel data (13 countries) & 1977-1992 & Tourist arrivals & GDP $\rightarrow$ TOUR \\
\hline Lee \& Chang (2008) & Panel data ( 23 countries) & $1990-2002$ & Tourism receipts, tourist arrivals & TOUR $\rightarrow$ GDP \\
\hline Sequeira \& Nunes (2008) & Panel data (94 countries) & $1980-2002$ & $\begin{array}{l}\text { Tourist arrivals, tourism receipts to } \\
\text { exports, tourism receipts to GDP }\end{array}$ & TOUR $\rightarrow$ GDP \\
\hline Proença \& Soukiazis (2008) & Panel data (4 countries) & $1990-2004$ & Tourism revenues & TOUR $\rightarrow$ GDP \\
\hline Soukiazis \& Proença (2008) & Panel data (Portuguese regions) & $1993-2001$ & Tourism receipts & TOUR $\rightarrow$ GDP \\
\hline Po \& Huang (2008) & Cross-section (88 countries) & $1980-2005$ & Tourism receipts & TOUR $\rightarrow$ GDP \\
\hline Adamou \& Clerides (2010) & Panel data (162 countries) & $1980-2005$ & Tourism receipts, tourist arrivals & TOUR $\rightarrow$ GDP \\
\hline Santana-Gallego et al. (2010) & Panel data (179 countries) & $1995-2006$ & Tourist arrivals & TOUR $\rightarrow$ GDP \\
\hline Holzner (2011) & Panel data (143 countries) & $1970-2007$ & Tourism receipts & - \\
\hline Marrocu \& Paci (2011) & Panel data (European regions) & $1985-2006$ & Tourist arrivals & - \\
\hline Caglayan et al. (2012) & Panel data (135 countries) & $1995-2008$ & Tourism receipts & $\begin{array}{l}\text { TOUR } \rightarrow \text { GDP } \\
\text { GDP } \rightarrow \text { TOUR }\end{array}$ \\
\hline Neves et al. (2015) & Panel data (Portuguese regions) & $1990-2007$ & Tourist arrivals & - \\
\hline
\end{tabular}

Note: the symbol $\rightarrow$ denotes the direction of causality. GDP $=$ Gross domestic product and TOUR = Tourism.

In the studies based on panel and cross-sectional data, in contrast to others based on time series, the tourism-led growth hypothesis is validated across a large sample of countries over many years. Certain studies, like those examining if the degree of economic development affects the validation of the tourism-led growth hypotesis, draw the conclusion that tourism acts as a factor of convergence in Portugal. The results appear to be in favour of tourism fostering the development of economic growth in the Portuguese regions (Proença \& Soukiazis, 2008; Soukiazis \& Proença, 2008). According to a recent study, the regions who contribute the most to Portuguese GDP are those who's tourism product is more differentiated (Neves, Fernandes, \& Pereira, 2015). One study found that the size of the country does not affect the relationship between tourism and economic growth (Sequeira \& Nunes, 2008).

\section{Data and econometric methods}

\subsection{Data collection}

This study employs quarterly and seasonally adjusted data for the period starting in the first quarter 1995 and ending in the first quarter of the year 2015. The data sample contains 81 observations for each variable. To compute real income we take the data from OECD Quarterly National Accounts (QNA) dataset on the basis of the System of National Accounts (ESA) 2010. The data is published in "Contas Nacionais Trimestrais Estimativas dos Principais Agregados" and compiled by
Instituto Nacional de Estatistica (INE) and provided to the $O E C D$ by Eurostat. The retrieved quarterly figures from the OECD database are already adjusted for seasonal variations with the X12 ARIMA method. We deflate the nominal GDP into real terms by dividing the seasonally adjusted quarterly levels of Gross domestic product (GDP), calculated using the expenditure approach and valued in current prices in millions euro, by the seasonally adjusted quarterly levels of the price deflator index $(2011=100)$. Then we multiply the result by 100 and read off the GDP in constant 2011 prices.

The tourism variable in this study is not aggregated. Tourist arrivals are chosen instead of tourism earnings to represent tourism due to data availability. A breakdown of tourist expenditure by monthly and quarterly frequency was not attainable. Tourist arrivals are retrieved from monthly data on tourism industries compiled in the accommodation statistics database (i.e. the capacity and occupancy of tourist accommodation establishments) by the Statistical Office of the European Union (Eurostat). The study employed data on arrivals of residents and non-residents at tourist accommodation establishments. The former stands for the proxy of domestic tourists and the latter measures foreign tourists. According to NACE Revision 2, tourist's accommodation establishments include hotels, holiday and short-stay accommodation; camping grounds, recreational vehicle parks and trailer parks. To match the frequency of the GDP data, the tourism variables are converted into quarterly 
observations, by taking the average of months in a quarter, and correspondingly seasonally adjusted with the X12 ARIMA method used by the U.S. Census Bureau for seasonal adjustment. For modelling purposes, the natural logarithms of the series were taken to make the skewed distribution of the variables more normal.

Graphical representation of the time series based on original data is presented in Fig. 1. A graphical analysis of the data reveals the existence of stages of growth and decline and a visible upward trend in almost all series. The graphs suggest that the period of economic downturn between 2008 and 2013 had a negative direct impact upon real GDP and the number of domestic tourists rather than on the volume of foreign tourists. Though, the initial strong seasonal patterns in the tourism-related data have been removed. Seasonality is an important feature of Portuguese tourism because it is in warmer months that the country is most sought by arrivals of tourists in tourist's accommodation establishments. Therefore, seasonality is an important feature of tourism and should be taken into account in the research design (Daniel \& Rodrigues, 2011).

\section{Figure 1 - Graphical representation of the data}
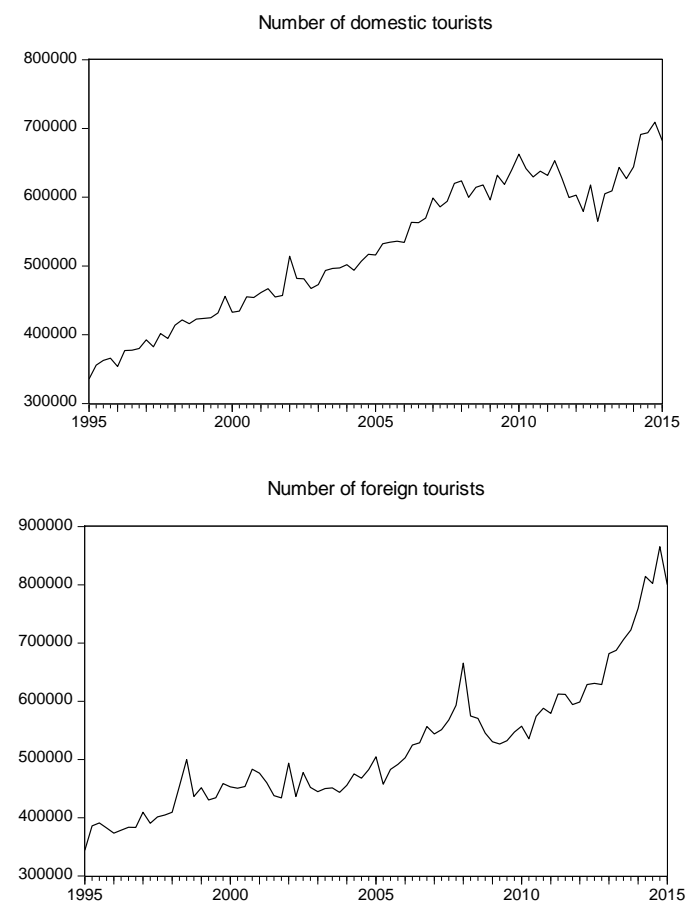

Real income in millions euro

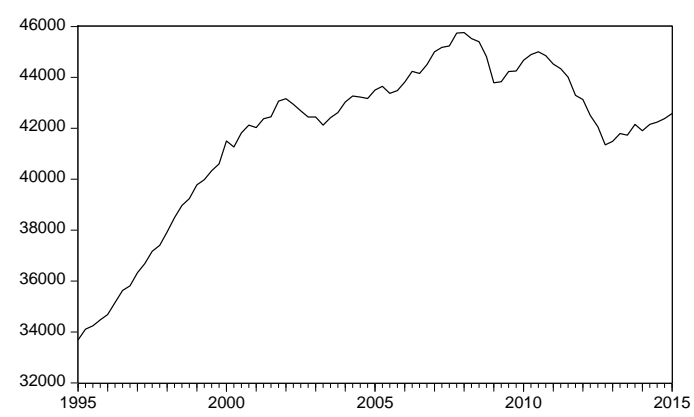

\subsection{Econometric approach}

3.2.1 Testing for unit roots
The time series properties of the data are first examined using the Augmented Dickey Fuller test (Dickey \& Fuller, 1979) with both an intercept and a linear time trend. The Schwartz information criterion is used for the selection of the optimal lag length. Visual inspection of the time series reveals a trend, and therefore the unit root test is performed with both an intercept and deterministic time trend using the equation as shown below.

$$
\Delta Y_{t}=\alpha_{0}+\alpha_{1} t+\beta Y_{t-1}+\sum_{j=1}^{p} \gamma_{j} \Delta Y_{t-j}+\varepsilon_{t}
$$

The difference operator is $\Delta$, and $\Delta Y_{t}=Y_{t}-Y_{t-1}, \alpha_{0}$ is a constant, $t$ is the deterministic trend, $p$ is the number of lags in the dependent variable $Y_{t}$, and $\varepsilon_{t}$ is the stochastic error term. This unit root testing procedure tests the null hypothesis $H_{0}$ : $B=0\left(Y_{t}\right.$ is non stationary) against the alternative $H_{1}: B<0\left(Y_{t}\right.$ is stationary). The variable is stationary if the null hypothesis is rejected if the value of the test statistic is less than the critical value. Enough lagged differences are included to ensure that the error term is white noise.

This study employs the Zivot-Andrews unit root tests with one single break in the intercept and in the trend (Zivot \& Andrews, 1992) to surpass a problem common with the conventional unit root tests, such as the ADF test, that does not allow for the possibility of a structural break. These stationarity tests possess therefore lower statistical power to reject the unit root null against the alternative of stationarity in the series in level form and in their first differences. By running the Zivot-Andrews test, the optimal number of lagged first differenced terms included in the unit root tests to correct for serial correlation is selected based on Schwarz Bayesian information criterion. This procedure is capable of estimating breakpoints and their corresponding $t$-statistics, which is then compare to the tabulated critical values at conventional levels. The case of both the trend and the intercept is chosen, where the time of break is chosen at the point that minimizes the one-sided $t$-statistic in the following equation:

$$
\Delta y_{t}=\mu+\alpha y_{t-1}+\beta_{t}+\Theta D U_{t}+\gamma D T_{t}+\sum_{j=1}^{k=1} c_{j} \Delta_{t-j}+\varepsilon_{t}
$$

The first difference operator $\Delta$ and the residuals $\varepsilon_{t}$ are assumed to be normally distributed and white noise. $D U_{t}$ and $D T_{t}$ are dummy variables that capture a structural break in the mean shift and slope shift occurring at time of break, respectively. $T B$ is the time of break, and $D U_{t}=1$ if $t>T B$ and zero otherwise. $D T_{t}$ is equal to $(t-T B)$ if $t>T B$ and zero otherwise. The null of a unit root with a structural break in both the intercept and the trend for a variable is rejected if the t-statistics is bigger than the critical values for the Zivot and Andrews test provided at conventional levels of statistical significance. In the unit root estimation with a structural break it is important to consider the trend propriety of the variables. If the series exhibit a trend, then estimating the model without the trend may fail to capture some important characteristics of the data changing the test power to reject the no-break null hypothesis (Ben-David \& Papell, 1998). Since the series in this 
study depict upward (or downward) trend, the unit root tests will therefore include a time trend in the test equations. This means that we optionally chose the Zivot-Andrews regression equation with the inclusion of the $\beta_{t}$ term. This model combines one-time change in the level and the slope of the trend function of the series.

\subsubsection{Testing for cointegration}

The Gregory and Hansen cointegration tests are applied to test the possible endogenous structural breaks in the data series and the underlying cointegration relationship among the variables (Gregory \& Hansen, 1996). This methodology tests the null hypothesis of no-cointegration against the alternative of cointegration with structural breaks. This procedure estimates models recursively since the time of the break is not known a priori and it searches endogenously for one break date. The single break date is endogenously determined and is selected by estimating the cointegration equations for all possible break dates in the data sample. For each possible breakpoint it computes the ADF statistics from the regression models and chooses the smallest value as the test statistic that is the most favorable for the rejection of the null. We test for cointegration in the model with level shift and trend as follows:

$$
\Delta y_{t}=\alpha_{0}+\mu_{1} \vartheta_{1}+\beta_{t}+\alpha x_{t}+\omega_{t}
$$

The Augmented Dickey-Fuller test and Phillips-Perron Za and $Z t$ tests are applied to the residuals $\omega_{t}$ obtained from the regression equation. The null hypothesis of no-cointegration is rejected if the statistics $A D F, Z a$ and $Z t$ are smaller than the corresponding critical value.

\subsubsection{Testing for Granger non-causality}

The usual Granger non-causality test leads to spurious regression results, and the $F$-test is not valid unless the variables in levels are cointegrated. The method for causal inference based on augmented VAR with lag order $(k)$ introduced by Toda and Yamamoto showed that Granger tests based upon the vector auto regression error-correction model (Johansen \& Juselius, 1990) are sensitive to the values of the nuisance parameters in finite samples and therefore their results are unreliable (Toda \& Yamamoto, 1995). The advantage of using this procedure is that it is not necessary to pretest the variables for their order of integration and cointegration properties. It handles non-stationary variables and avoids pretest biases sensitivity. It uses a Modified Wald test for restrictions on the parameters of the VAR $(k)$ model and assumes an asymptotic Chi-squared distribution with $k$ degrees of freedom in the limit when a $\operatorname{VAR}(k+d(\max ))$ is estimated where $d$ ( $\max$ ) is the maximal order of integration for the series in the system.

This procedure involves two steps. The first step determines the lag length $(k)$ and the maximum order of integration $(d)$ of the variables in the system. For this purpose the Schwartz Bayesian information criterion is used to determine the appropriate lag structure of the VAR. Once VAR $(k)$ is selected, and the order of integration $d(\max )$ is chosen, a level VAR is estimated with a total of $p=(k+d(\max ))$ lags. The second step deals with the standard Wald tests and the Granger causality analysis using the Seemingly Unrelated Regression (SUR) technique through the estimating of a two equations system specified as follows:

$$
\begin{gathered}
Y_{t}=\alpha_{1}+\sum_{i=1}^{k+d} \gamma_{1 i} Y_{t-i}+\sum_{t-i}^{k+d} \gamma_{2 i} X_{t-i}+\varepsilon_{y t} \\
X_{t}=\alpha_{2}+\sum_{i=1}^{k+d} \delta_{1 i} Y_{t-i}+\sum_{t-i}^{k+d} \delta_{2 i} X_{t-i}+\varepsilon_{x t}
\end{gathered}
$$

In the equation above $k$ is the optimal lag order, $d$ is the maximal order of integration of the series in the system, and $\varepsilon_{y t}$ and $\varepsilon_{x t}$ are error terms that are assumed to be white noise. The procedure tests the null hypothesis that $X_{t}$ "Grangercauses" $Y_{t}$ if $\gamma_{2 i} \neq 0$ against the alternative hypothesis that $Y_{t}$ "Granger-causes" $X_{t}$ if $\delta_{1 i} \neq 0$. Granger causality, also referred to as causation, implies that when, for example, $X$ causes $Y$ and $Y$ does not cause $X$, then the test reveals so-called one-way causality. It is also known as unidirectional causality running from $X$ to $Y$. When variable $X$ and $Y$ are jointly determined, then the direction of causality goes both ways, and we infer bidirectional causality. If there is cointegration among the variables then there must be at least one occurrence of Granger causality either unidirectional or bidirectional (Granger, 1986).

\section{Empirical results}

The descriptive statistics and pair wise correlations among the variables are reported in Table 2 and Table 3. The correlation matrix reveals that domestic tourists and foreign tourists are positively correlated with real GDP. Foreign tourists are positively correlated with domestic tourists. All variables are statistically significant at conventional statistical levels.

Table 2 - Descriptive statistics

\begin{tabular}{|l|c|c|c|}
\hline GDP & $\begin{array}{c}\text { Domestic } \\
\text { tourists }\end{array}$ & $\begin{array}{c}\text { Foreign } \\
\text { tourists }\end{array}$ \\
\hline Mean & 10.63 & 13.15 & 13.14 \\
\hline Median & 10.65 & 13.15 & 13.10 \\
\hline Maximum & 10.73 & 13.47 & 13.67 \\
\hline Minimum & 10.42 & 12.72 & 12.74 \\
\hline Standard deviation & 0.07 & 0.19 & 0.20 \\
\hline Coefficient of variation & 0.01 & 0.01 & 0.01 \\
\hline
\end{tabular}

Note: the coefficient of variation is the standard deviation-to-mean ratio.

Table 3 - Correlation matrix

\begin{tabular}{|l|c|c|c|}
\hline & GDP & $\begin{array}{c}\text { Domestic } \\
\text { tourists }\end{array}$ & $\begin{array}{c}\text { Foreign } \\
\text { tourists }\end{array}$ \\
\hline GDP & 1 & & \\
\hline Domestic tourists & $0.82^{*}$ & 1 & \\
\hline Foreign tourists & $0.61^{*}$ & $0.90^{*}$ & 1 \\
\hline
\end{tabular}

Note: the symbol * denotes statistical significance at $1 \%$ level.

The results of the unit root tests using augmented DickeyFuller are summarized in Table 4. As expected, the results of the unit root tests conducted on both the level and first differences of the lagged variables indicate that the variables at their levels are not stationary. 
Table 4 - Results of the unit root tests

\begin{tabular}{|c|c|c|c|c|c|}
\hline \multirow[b]{3}{*}{ Variables } & \multicolumn{5}{|c|}{ Unit root tests } \\
\hline & \multicolumn{2}{|c|}{ Augmented Dickey-Fuller } & \multicolumn{3}{|c|}{ Zivot-Andrews } \\
\hline & Level & First difference & Lag length & Break Time & Min. T-test statistic \\
\hline GDP & -1.67 & $-6.75^{*}$ & 2 & 2006Q2 & -2.53 \\
\hline Domestic tourists & -2.32 & $-13.63^{*}$ & 1 & 2011Q4 & -4.66 \\
\hline Foreign tourists & -3.26 & $-12.46^{*}$ & 1 & 2008Q4 & -3.74 \\
\hline
\end{tabular}

Note: the symbol* denotes statistical significance at $5 \%$, respectively. The ADF unit root test is with trend and intercept in level and first difference. The critical values for the ADF test are $-4.08,-3.47,-3.16$ at the $1 \%, 5 \%$, and $10 \%$ levels of significance respectively. The number of lags is chosen with the Schwartz information criterion. The critical values for Zivot-Andrews unit root test with a structural break in both the intercept and trend are $-5.57,-5.08,-4.82$ at $1 \%, 5 \%$, and $10 \%$ levels of significance respectively.

The ADF tests indicate that they are stationary in the first difference form (where the null hypothesis of unit root can be rejected at the $5 \%$ level of significance). The conventional unit root test indicates that all variables are non-stationary at the levels and become difference stationary variables integrated of order one.

The results for Zivot and Andrew unit root test are presented in Table 4 and for consistency we compare the results from Zivot-Andrews test and the conventional unit root test at the 5 per cent significance level. These results suggest that we fail to reject the null of unit root at 5 per cent significance level for the variables. This finding clearly does not contradict the results obtained from the unit root test without structural breaks for all series. The test identifies endogenously the point of the single most significant structural break for each series. Generally, the years 2008 and 2011 can be associated with the period of economic downturn between 2008 and 2013.
The results for Gregory-Hansen cointegration tests are given in Table 5. These results imply that in the model with structural breaks there is cointegration between the variables of interest. According to the two statistics ADF*, Zt* they detect cointegration at the $5 \%$ significance level since the null hypothesis of no cointegration is rejected in the model with structural breaks. Based on the test outcome, there is a cointegration relationship among real GDP, domestic tourists and foreign tourists in the presence of structural breaks. Based on all three statistics, ADF*, $\mathrm{Zt}^{*}$ and $\mathrm{Za}^{*}$, the year 1998 has been identified by the Gregory-Hansen cointegration procedure as the year of structural break. That year corresponds to the year the country had qualified for the Economic and Monetary Union of the European Union (EMU). In the second half of the nineties, the prospect to entry in the euro led to an output boom and large current account deficits in Portugal (Blanchard, 2007).

Table 5 - Results of the Gregory and Hansen cointegration tests

\begin{tabular}{|c|c|c|c|c|}
\hline Test & Test statistic & $\boldsymbol{k}$ & Break date & Reject null hypothesis of no cointegration \\
\hline ADF* & -5.43 & 0 & $1998 \mathrm{Q} 3$ & yes \\
\hline $\mathrm{Zt}^{*}$ & -5.36 & - & $1998 \mathrm{Q} 3$ & yes \\
\hline $\mathrm{Z} \alpha^{*}$ & -40.57 & - & $1998 \mathrm{Q} 3$ & no \\
\hline
\end{tabular}

Note: the Gregory-Hansen cointegration test includes a level shift with trend, and the critical values at $1 \%, 5 \%$, and $10 \%$ significance levels are $-5.47,-4.95$, and -4.68 for $\mathrm{ADF}^{*}, \mathrm{Zt}^{*}$, and $-57.28,-47.96$, and -43.22 for $\mathrm{Z}^{*}$.

The results of the Granger non-causality tests based on the application of the Toda-Yamamoto testing procedure are reported in Table 6. We fail to reject Granger non-causality when employing the Toda-Yamamoto test. Results of the analysis show that there is a causal relation among domestic tourists and real GDP. The empirical findings demonstrate a significant long run unidirectional causality running from domestic tourists to real GDP, but not vice versa. As a check on the accuracy of our findings we can compare the results from the causality analysis with those from previous studies in the field that employ causal inferences within the tourism-led growth hypothesis (Lee \& Chang, 2008; Sequeira \& Nunes, 2008; Proença \& Soukiazis, 2008; Po \& Huang, 2008; Adamou \& Clerides, 2010, Santana-Gallego et al., 2010; Caglayan et al., 2012). After detecting the cointegration relationship among the variables, we depicted a direct causal connection between tourist arrivals and economic growth. This result is inferred from a single country study with time series techniques. The findings are related to the aforementioned panel data studies.
Table 6 - Results of the Toda and Yamamoto causality tests

\begin{tabular}{|l|c|}
\hline Null hypothesis and direction of causality & $\begin{array}{c}\text { Modified Wald Chi- } \\
\text { square statistic }\end{array}$ \\
\hline $\begin{array}{l}\text { Domestic tourists does not Granger cause } \\
\text { GDP }\end{array}$ & $9.80^{*}$ \\
\hline $\begin{array}{l}\text { Foreign tourists does not Granger cause } \\
\text { GDP }\end{array}$ & 0.66 \\
\hline $\begin{array}{l}\text { GDP does not Granger cause domestic } \\
\text { tourists }\end{array}$ & 6.28 \\
\hline $\begin{array}{l}\text { Foreign tourists does not Granger cause } \\
\text { domestic tourists }\end{array}$ & 1.24 \\
\hline $\begin{array}{l}\text { GDP does not Granger cause foreign } \\
\text { tourists }\end{array}$ & 1.68 \\
\hline $\begin{array}{l}\text { National tourists does not Granger cause } \\
\text { foreign tourists }\end{array}$ & 0.72 \\
\hline
\end{tabular}

Note: the symbol $*$ denotes statistical significance at the $5 \%$ level. All estimates are modified Wald chi-square statistics to test whether the number of lags is equal to zero. The lag intervals for endogenous variables are set to 4 in the unrestricted VAR. All models are free of serial correlation and autoregressive conditional heteroscedasticity. The inverse roots graph indicates that the estimated models are also dynamically stable. 


\section{Conclusion}

While the relationship between tourism and economic growth has been one of the main research topics in recent literature, the study contributes to the existing literature by testing the tourism-led growth hypothesis in Portugal by distinguishing between domestic and international tourist arrivals. This study has used a disaggregated measure of tourism activity to provide additional information about the effects of domestic tourism and foreign tourism on economic growth. The results from the cointegration and causality tests support the view that the tourism-led growth hypothesis is valid for the Portuguese economy. The findings show that there is a causal link between tourism and economic growth. Tourism does really matter for economic growth in Portugal. The results are indicative of a causal link amongst domestic tourists and economic growth, and therefore this study confirms that tourism is an important source of economic growth.

The central policy implication thus emanating from these findings is that policy makers should pay attention to not only to foreign tourists, but all domestic tourists as well. Despite the contribution of our findings, this study is not without any limitations. In fact, little is known about how the tourism-led growth relationship occurs and what are the enablers of the domestic tourism activity growth (i.e. airlines, hotels, restaurants, and travel and trekking agencies). A profitable avenue for future research, therefore, would be to investigate the tourism-led growth hypothesis at the local and regional level. Furthermore, taking into account research that determines the factors influencing the domestic tourism sector and relate general economic conditions and prospects to tourism, may serve as the basis for future research.

\section{Acknowledgments}

The author would like to thank the efforts put into improving the manuscript by two anonymous reviewers. Preliminary versions of this paper have been presented at VI Postgraduate Conference of School of Management, Hospitality and Tourism on July 10, 2015 at the School of Management, Hospitality and Tourism, University of the Algarve, and at 1st edition of MIST (Modelling Innovation Sustainability and Technologies), 22-23 October 2015, at University Atlântica in Oeiras (Lisbon).

\section{References}

Akkemik, K. A. (2012). Assessing the importance of international tourism for the Turkish economy: A social accounting matrix analysis. Tourism Management, 33, 790-801.

Archer, B. (1995). Importance of tourism for the economy of Bermuda. Annals of Tourism Research, 22, 918-930.

Balaguer, J., \& Cantavella-Jordá, M. (2002). Tourism as a long run economic growth factor: the Spanish case. Applied Economics, 34, 877884.

Ben-David, D., \& Papell, D. H. (1998). Slowdowns and meltdowns: Postwar growth evidence from 74 countries. Review of Economics and Statistics, 80, 561-571.

Blanchard, O. (2007). Adjustment within the euro. The difficult case of Portugal. Portuguese Economic Journal, 6, 1-21.

Brida, J. G., Carrera, S. E., \& Risso, W. A. (2008). Tourism's impact on long run Mexican economic growth. Economic Bulletin, 3, 1-8.
Brida, J. G., \& Giuliani, D. (2013). Empirical assessment of the tourismled growth hypothesis: the case of the Tirol, Südtirol, Trentino Europaregion. Tourism Economics, 19, 745-760.

Carrascal Incera, A., \& Fernández, M. F. (2015). Tourism and income distribution: Evidence from a developed regional economy. Tourism Management, 48, 11-20.

Corrie, K., Stoeckl, N., \& Chaiechi, T. (2013). Tourism and economic growth in Australia: an empirical investigation of causal links. Tourism Economics, 19, 1317-1344.

Cortés-Jiménez, I., \& Pulina, M. (2010). Inbound tourism and long run economic growth. Current Issues in Tourism, 13, 61-74.

Daniel, A., \& Rodrigues, P. (2010). Volatility and seasonality of tourism demand in Portugal. In Economic Bulletin (pp. 87-102). Lisboa: Banco de Portugal.

Daniel, A., \& Rodrigues, P. (2011). Modelling Tourism demand in Portugal. In A. Matias, P. Nijkamp \& S. M. (Eds.), Tourism Economics: Impact Analysis (pp. 79-94). Berlin: Springer.

Dickey, D. A., \& Fuller, W. A. (1979). Distribution of the estimators for autoregressive time series with a unit root. Journal of the American Statistical Association, 74, 427-431.

Dritsakis, N. (2004). Tourism as a long run economic growth factor: an empirical investigation for Greece using causality analysis. Tourism Economics, 10, 305-316.

Eeckels, B., Filis, G., \& Leon, C. (2012). Tourism income and economic growth in Greece: empirical evidence from their cyclical components. Tourism Economics, 18, 817-834.

Ghali, M. A. (1976). Tourism and Economic Growth: An Empirical Study. Economic Development and Cultural Change, 24, 527-538.

Granger, C. W. J. (1986). Developments in the study of cointegrated economic variables. Oxford Bulletin of Economics and Statistics, 48, 213-228.

Gregory, A. W., \& Hansen, B. E. (1996). Residual-based tests for cointegration in models with regime shifts. Journal of Econometrics, 70, 99-126.

Gunduz, L., \& Hatemi-J, A. (2005). Is the tourism-led growth hypothesis valid for Turkey? Applied Economics Letters, 12, 499-504.

Johansen, S., \& Juselius, K. (1990). Maximum likelihood estimation and inference on cointegration - with applications to the demand for money. Oxford Bulletin of Economics and Statistics, 52, 169-210.

Katircioglu, S. (2007). Tourism, trade and growth: The case of Cyprus. Applied Economics, 41, 2741-2750.

Katircioglu, S. (2009). Testing the tourism-led growth hypothesis: The case of Malta. Acta Oeconomica, 59, 331-343.

Katircioglu, S. T. (2009). Revising the tourism-led-growth hypothesis for Turkey using the bounds test and Johansen approach for cointegration. Tourism Management, 30, 17-20.

Kim, H. J., Chen, M.-H., \& Jang, S. S. (2006). Tourism expansion and economic development: The case of Taiwan. Tourism Management, 27, 925-933.

Lanza, A., \& Pigliaru, F. (2000). Tourism and economic growth: does country size matter? Rivista Internazionale di Scienze Economiche e Commerciali, 77-85.

Marin, D. (1992). Is the Export-Led Growth Hypothesis Valid for Industrialized Countries? The Review of Economics and Statistics, 74, 678-688.

Massidda, C., \& Mattana, P. (2013). A SVECM analysis of the relationship between inter- national tourism arrivals, GDP and trade in Italy. Journal of Travel Research, 52, 93-105. 
Munjal, P. (2013). Measuring the economic impact of the tourism industry in India using the Tourism Satellite Account and input-output analysis. Tourism Economics, 19, 1345-1359.

Neves, D. C., Fernandes, A. J., \& Pereira, E. T. (2015). Determinants of touristic attraction in Portuguese regions and their impact on GDP. Tourism Economics, 21, 629-648.

Nowak, J.-J., Sahli, M., \& Cortés-Jiménez, I. (2007). Tourism, capital good imports and economic growth: theory and evidence for Spain. Tourism Economics, 13, 515-536.

Pérez-Rodríguez, J. V., Ledesma-Rodríguez, F., \& Santana-Gallego, M. (2015). Testing dependence between GDP and tourism's growth rates. Tourism Management, 48, 268-282.

Proença, S., \& Soukiazis, E. (2008). Tourism as a long run economic growth factor: A case study for Southern European countries. Tourism Economics, 14, 791-806.

Schubert, S. F., Brida, J. G., \& Risso, W. A. (2011). The impacts of international tourism demand on economic growth of small economies dependent on tourism. Tourism Management, 32, 377-385.

Sequeira, T. N., \& Nunes, P. M. (2008). Does tourism influence economic growth? A dynamic panel data approach. Applied Economics, 40, 2431-2441.

Soukiazis, E., \& Proença, S. (2008). Tourism as an alternative source of regional growth in Portugal: a panel data analysis at NUTS II and III levels. Portuguese Economic Journal, 7, 43-61.

Tang, C. F., \& Tan, E. C. (2013). How stable is the tourism-led growth hypothesis in Malaysia? Evidence from disaggregated tourism markets. Tourism Management, 37, 52-57.

Toda, H. Y., \& Yamamoto, T. (1995). Statistical inference in vector autoregressions with possibly integrated processes. Journal of Econometrics, 66, 225-250.

West, G. R. (1993). Economic significance of tourism in Queensland. Annals of Tourism Research, 20, 490-504.

WTTC. (2015). Travel \& Tourism. Economic Impact 2014. Portugal. In: World Travel \& Tourism Council. Retrieved June 3, 2015 from http://www.wttc.org/- /media/files/reports/economic\%20impact\%20 research/countries\%202015/portugal2015.pdf.

Zivot, E., \& Andrews, D. W. K. (1992). Further evidence on the great crash, the oil-price shock, and the unit-root hypothesis. Journal of Business \& Economic Statistics, 10, 251-270.

\section{Article history:}

Submitted: 30.06 .2015

Received in revised form: 06.01.2016

Accepted: 19.01.2016 